\title{
Kisspeptin and Gonadotropin-Releasing Hormone Neuronal Excitability: Molecular Mechanisms Driven by $17 \beta$-Estradiol
}

\author{
Oline K. Rønnekleiv ${ }^{a}$ b Chunguang Zhang ${ }^{a}$ Martha A. Bosch ${ }^{a}$ \\ Martin J. Kelly ${ }^{a, b}$

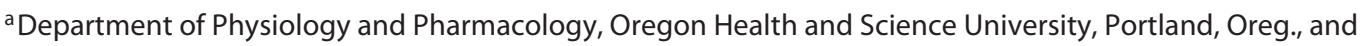 \\ ${ }^{b}$ Division of Neuroscience, Oregon National Primate Research Center, Beaverton, Oreg., USA
}

\author{
Key Words \\ Canonical transient receptor potential channels . \\ Gonadotropin-releasing hormone - Kisspeptin . \\ T-type calcium current $\cdot$ Hyperpolarization-activated, \\ cyclic nucleotide-gated current . Persistent sodium current
}

channels that are important for burst firing. Therefore, $E_{2}$ modulates the excitability of GnRH neurons as well as of Kiss 1 neurons by altering the expression and/or function of ion channels; moreover, kisspeptin provides critical excitatory input to $\mathrm{GnRH}$ neurons to facilitate burst firing activity and peptide release.

(c) 2015 S. Karger AG, Basel

\begin{abstract}
Kisspeptin is a neuropeptide that signals via a Gaq-coupled receptor, GPR54, in gonadotropin-releasing hormone (GnRH) neurons and is essential for pubertal maturation and fertility. Kisspeptin depolarizes and excites $\mathrm{GnRH}$ neurons primarily through the activation of canonical transient receptor potential (TRPC) channels and the inhibition of $\mathrm{K}^{+}$channels. The gonadal steroid $17 \beta$-estradiol $\left(E_{2}\right)$ upregulates not only kisspeptin (Kiss1) mRNA but also increases the excitability of the rostral forebrain Kiss1 neurons. In addition, a primary postsynaptic action of $E_{2}$ on $\mathrm{GnRH}$ neurons is to upregulate the expression of channel transcripts that orchestrate the downstream signaling of kisspeptin in GnRH neurons. These include not only TRPC 4 channels but also low-voltage-activated T-type calcium channels and high-voltage-activated L-, $\mathrm{N}$ - and R-type calcium channel transcripts. Moreover, $\mathrm{E}_{2}$ has direct membrane-initiated actions to alter the excitability of GnRH neurons by enhancing ATP-sensitive potassium channel activity, which is critical for maintaining GnRH neurons in a hyperpolarized state for the recruitment of T-type calcium
\end{abstract}

\section{KARGER}

E-Mail karger@karger.com

www.karger.com/nen (c) 2015 S. Karger AG, Basel

0028-3835/15/1023-0184\$39.50/0

\section{Introduction}

Gonadotropin-releasing hormone (GnRH) neurosecretion and the control of the ovulatory cycle in females is dependent on estrogen feedback, primarily $17 \beta$-estradiol $\left(E_{2}\right)$ secreted from the ovaries which reaches the pituitary and the brain via the circulation. $\mathrm{E}_{2}$ treatment in ovariectomized females initially inhibits $\mathrm{GnRH}$ and luteinizing hormone $(\mathrm{LH})$ secretion by the process known as negative feedback, followed by $\mathrm{E}_{2}$-induced super-secretion (positive feedback) in a speciesspecific manner 12-42 h later [1-3]. With the development of mouse and rat models in which GnRH neurons express enhanced green fluorescent protein, it has been possible to systematically study these neurons in order to evaluate the GnRH neuronal excitability and activity with the ultimate goal of understanding the neuronal activity underlying the different secretory patterns uti- 
lized by these cells [4-6]. In addition, kisspeptin neurons, located in the anteroventral and more caudal periventricular preoptic area $(\mathrm{AVPV} / \mathrm{PeN})$, express the $\mathrm{E}_{2}$ receptor- $\alpha(E R \alpha)$, and $E_{2}$ stimulates Kiss 1 mRNA expression in this brain region [7]. Moreover, kisspeptin is one of the most potent excitatory neurotransmitters of GnRH neurons [8-11].

Based on decades of intracellular sharp electrode and whole-cell recordings in a number of parvocellular hypothalamic neurons, we have modeled currents crucial for rhythmic burst firing and have continued to explore the role of these currents in GnRH and, more recently, in Kiss1 neurons [12-14]. These currents include the lowthreshold T-type calcium current $\left(\mathrm{I}_{\mathrm{T}}\right)$, the hyperpolarization-activated, cyclic nucleotide-gated current $\left(\mathrm{I}_{\mathrm{h}}\right)$, a calcium-dependent, afterhyperpolarization potassium current $\left(\mathrm{I}_{\mathrm{AHP}}\right)$ as well as a persistent, sodium current $\left(\mathrm{I}_{\mathrm{NaP}}\right)$, all of which will be further discussed in this review (fig. 1). All of these currents have been studied extensively in thalamic relay neurons, in which the T-current is responsible for low-threshold calcium spikes and the h-current serves as the 'pacemaker' to control the rate of rhythmic oscillations in these neurons [15-17]. Recently, several models have been developed that include an ensemble of channels that appear to be critical for burst firing in parvocellular neurosecretory neurons $[12,18-20]$. Variations of these models have been described in a number of reviews and primary publications [21-30] and therefore will not be extensively covered in this minireview. Rather, this review will focus on the $\mathrm{E}_{2}$ modulation of both $\mathrm{GnRH}$ neurons and the presynaptic kisspeptin neurons as well as discuss the role of kisspeptin as a unique excitatory neurotransmitter of GnRH neurons.

\section{$E_{2}$ Modulation of GnRH Neuronal Activity through Channel Expression}

As in thalamic neurons, $\mathrm{I}_{\mathrm{T}}, \mathrm{I}_{\mathrm{h}}, \mathrm{I}_{\mathrm{AHP}}$ and $\mathrm{I}_{\mathrm{NaP}}$ are important for burst firing in GnRH as well as in AVPV/PeN Kiss1 neurons [14, 15, 17, 22, 25, 31-34]. We and others have continued to explore the modulation of these currents by $\mathrm{E}_{2}$ in $\mathrm{GnRH}$ and Kiss1 neurons in order to elucidate the conductances underlying burst firing activity.

Three subunits of the T-type calcium channel $\left(\mathrm{Ca}_{\mathrm{V}} 3.1\right.$, 3.2 and 3.3) have been cloned, with the specific gating properties of the channel being dependent on its subunit composition [35, 36]. Thus, the kinetic properties of channels composed of $\mathrm{Ca}_{\mathrm{v}} 3.1$ and $\mathrm{Ca}_{\mathrm{v}} 3.2$ subunits are different from those of $\mathrm{Ca}_{\mathrm{v}} 3.3$ subunits [37]. GnRH neu- rons express all three of the T-type calcium channel subunits, and the $\mathrm{I}_{\mathrm{T}}$ in GnRH neurons shows different types of inactivation kinetics, with the slow $\mathrm{Ca}_{\mathrm{V}} 3.3$ channel being the most prominent of the three $[32,38]$. It is of importance that $\mathrm{I}_{\mathrm{T}}$ is present in the majority of GnRH neurons, and the membrane potential at which half of the T-type calcium channels are available for activation (i.e., are de-inactivated) is $-80 \mathrm{mV}$ [32]. As found in other neuronal systems, the role of $\mathrm{I}_{\mathrm{T}}$ is to initiate transient membrane depolarizations which recruit high-voltage-activated (HVA) calcium channels to increase calcium influx $[39,40]$. This is of functional significance since HVA calcium currents are prevalent in GnRH neurons [41], but they can only be activated from a more depolarized state, whereas low-voltage-activated T-type currents are recruited from a more hyperpolarized state (i.e., they provide the signal for setting off burst firing) [32, 38, 41-44]. Importantly, the T-type $\mathrm{Ca}_{\mathrm{V}} 3.3$ channel subunit expression and current density are significantly enhanced with a high $\mathrm{LH}$ surge-inducing $\mathrm{E}_{2}$ treatment, facilitating the excitation of GnRH neurons [32]. Therefore, the $\mathrm{E}_{2}$-dependent increase in T-type calcium channels may serve to augment the excitability of GnRH neurons in preparation for the $\mathrm{GnRH}$ (and LH) surge. In addition, the majority of HVA channel subtypes are expressed in GnRH neurons, and the mRNA levels of the L-type HVA calcium channel $\mathrm{Ca}_{V} 1.3$, the N-type HVA calcium channel $\mathrm{Ca}_{\mathrm{V}} 2.2$, and the R-type HVA calcium channel $\mathrm{Ca}_{\mathrm{V}} 2.3$ are also increased by LH surge-inducing $\mathrm{E}_{2}$ treatment [45]. Similarly, L- and $\mathrm{N}$-type currents are increased by $\mathrm{E}_{2}$ during the afternoon as compared to the morning in an $\mathrm{E}_{2}$ implant model that induces daily LH surges $[41,46]$. Collectively, these findings suggest a prominent role for calcium channels in the $E_{2}$-induced excitation of $\mathrm{GnRH}$ neurons. GnRH neurons also express a hyperpolarization-activated, cyclic nucleotide-gated cation current $\left(\mathrm{I}_{\mathrm{h}}\right.$; the pacemaker current), which also contributes to rhythmic firing $[18,33,47,48]$. Two $\mathrm{I}_{\mathrm{h}}$ channel mRNAs, HCN1 and HCN2, are highly expressed in mouse GnRH neurons, and the mRNA expression of $\mathrm{HCN} 1$ is upregulated by $\mathrm{E}_{2}$ [45]. Although $\mathrm{E}_{2}$ regulation of the h-current has not been evaluated in female GnRH neurons, $\mathrm{I}_{\mathrm{h}}$ is upregulated by $\mathrm{E}_{2}$ in Kiss1 neurons, an indication that this current is $\mathrm{E}_{2}$ sensitive [14, 34].

Critical for hyperpolarizing the membrane to de-inactivate and recruit $\mathrm{I}_{\mathrm{T}}$ and activate $\mathrm{I}_{\mathrm{h}}$ are the inwardly rectifying $\mathrm{K}^{+}\left(\mathrm{K}_{\mathrm{ir}}\right)$ channels. It is well known that $\mathrm{K}_{\mathrm{ir}}$ channels are vital for maintaining excitable cells in a hyperpolarized resting state closer to the Nernst equilibrium potential for potassium, but once cells are depolarized, 


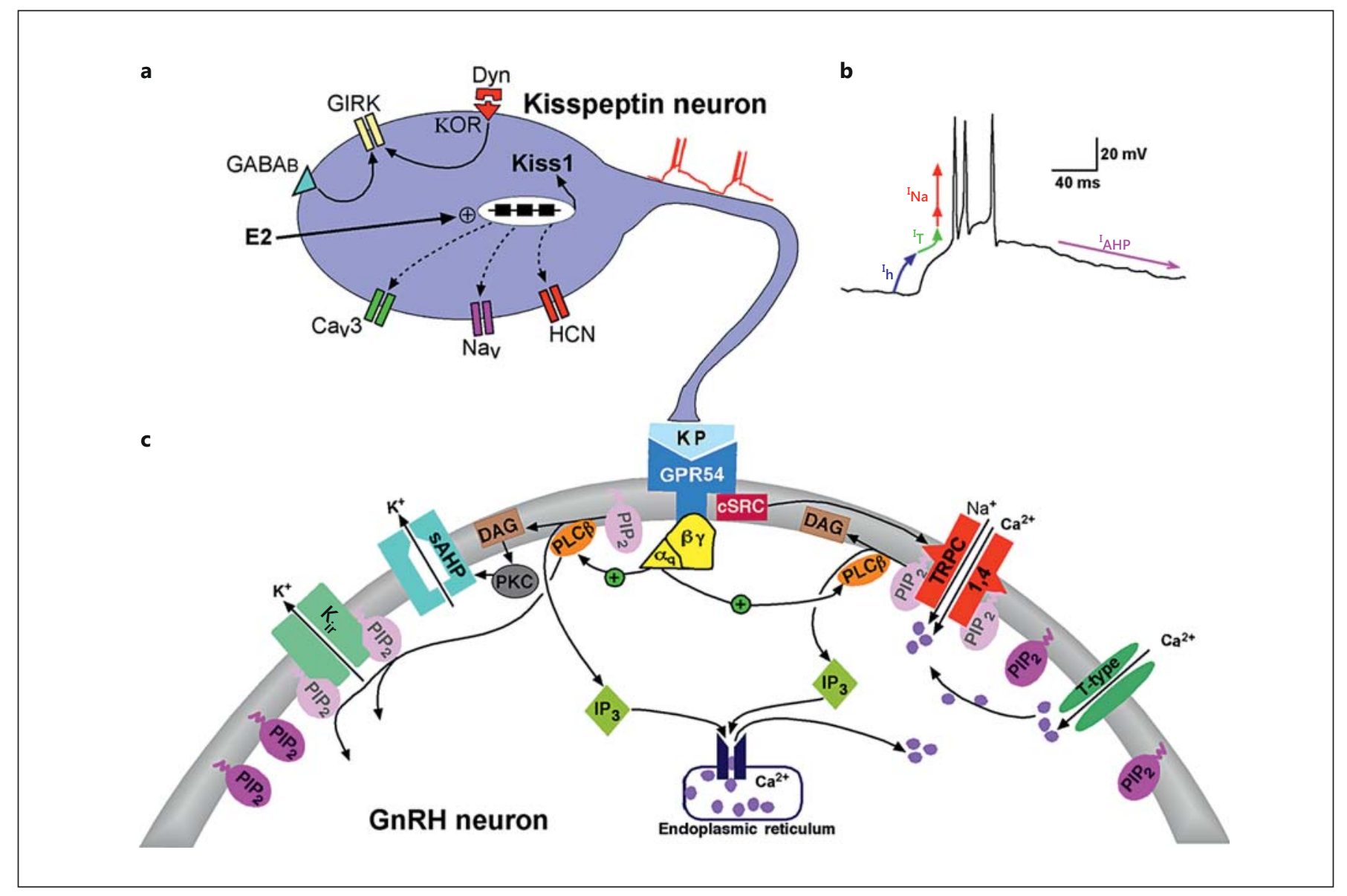

Fig. 1. Schematic diagram illustrating the Kiss1-GnRH connection and signaling pathways responsible for kisspeptin-induced depolarization and burst firing of GnRH neurons. a Kisspeptin neurons express the conductances ( $\mathrm{h}, \mathrm{T}$ and $\mathrm{NaP}$ ) and corresponding channels $\left(\mathrm{HCN}, \mathrm{Ca}_{\mathrm{V}} 3\right.$ and $\left.\mathrm{Na}_{\mathrm{V}}\right)$ that generate burst firing necessary for the maximum release of kisspeptin from the nerve terminal. $\mathrm{E}_{2}$ treatment increases the mRNA expression of Kiss1. In addition, the critical currents $\left(\mathrm{I}_{\mathrm{h}}\right.$ and $\left.\mathrm{I}_{\mathrm{T}}\right)$ are increased by circulating $\mathrm{E}_{2}$. The respective ion channel transcripts $\left(\mathrm{HCN}, \mathrm{Ca}_{\mathrm{V}} 3\right.$ as well as $\left.\mathrm{Na}_{\mathrm{V}}\right)$ are also expressed in Kiss 1 neurons (dashed lines). $\mathrm{E}_{2}$ regulation of the mRNA expression of these channels is under investigation (manuscript in preparation). Kiss 1 neurons also express $G_{A B A}$ and $\kappa$-opioid receptors (KOR) which couple to GIRK channels. b Whole-cell current-clamp recording of spontaneous rebound burst firing recorded from an AVPV/PeN Kiss1 neuron. Arrows

the channels allow for the quick transition to long depolarizing responses because of their inwardly rectifying properties [49]. With greater membrane hyperpolarization of GnRH neurons, there is an increase in the number of $\mathrm{Na}^{+}$spikes generated during the rebound excitation [Zhang et al., unpubl. obs.]. Indeed, ATP-sensitive potassium $\left(\mathrm{K}_{\mathrm{ATP}}\right)$ and $\mathrm{G}$-protein-coupled inwardly rectifying indicate the approximate range where the $\mathrm{I}_{\mathrm{h}}$ (blue), $\mathrm{I}_{\mathrm{T}}$ (green) and persistent $\mathrm{Na}^{+}$current $\left(\mathrm{I}_{\mathrm{Na}}\right.$, first red arrow) are active to depolarize the cell to the threshold for generating an ensemble of fast $\mathrm{Na}^{+}$ spikes $\left(\mathrm{I}_{\mathrm{Na}}\right.$, second red arrow) and $\mathrm{I}_{\mathrm{AHP}}$ (magenta) to repolarize the membrane to a hyperpolarized state to reinitiate the burst firing. The $\mathrm{I}_{\mathrm{Na}}$ is composed of an initial $\mathrm{I}_{\mathrm{Nap}}$ followed by an $\mathrm{I}_{\mathrm{NaT}}$ (transient Na current). c Kisspeptin binds to the Gq-coupled GPR54 receptor to activate phospholipase $\mathrm{C} \beta$ (PLC $\beta$ ), which catabolizes $\mathrm{PIP}_{2}$, potentiates TRPC channel activity and inhibits the $\mathrm{K}_{\mathrm{ir}}$ channel activity. PKC, activated by the PIP $_{2}$ hydrolysis product diacylglycerol (DAG), inhibits the activity of a calcium-activated sAHP current. The cSRC kinase, which is activated by kisspeptin/GRP54 signaling, potentiates the activity of TRPC4 channels. Calcium entering the cell via T-type channels facilitates the activation of TRPC channels.

potassium (GIRK) channels appear to be the critical $\mathrm{K}_{\mathrm{ir}}$ channels in GnRH neurons for maintaining the membrane in a more negative resting state. Blocking $\mathrm{K}_{\mathrm{ATP}}$ channels significantly depolarizes GnRH neurons, which is indicative of tonic $\mathrm{K}_{\mathrm{ATP}}$ channel activity that is significantly augmented with $\mathrm{E}_{2}$ treatment [48]. Also, GABA, opioids, neuropeptide $\mathrm{Y}$ and perhaps melanin-concen- 
trating hormone inputs via their respective $G_{A B A}$, $\mu$-opioid, Y5 and MCH1 receptors activate GIRK channels to hyperpolarize GnRH neurons [47, 50-52]. This combination of hyperpolarizing influences would allow for the recruitment of multiple excitatory conductances that are critical for generating burst firing in central nervous system neurons $[15,18]$.

Neuronal excitability is also determined by the afterhyperpolarization (AHP) that follows an action potential, and the three kinds of calcium-activated potassium channels that mediate AHPs have been identified in $\mathrm{GnRH}$ neurons [25, 53-56]. This includes the fast AHP, which is mediated by the large-conductance $\mathrm{Ca}^{2+}$-activated $\mathrm{K}^{+}$ (BK) channels, the medium AHP (mAHP), which is mediated by small-conductance, calcium-activated $\mathrm{K}^{+}(\mathrm{SK})$ channels, and the slow AHP (sAHP), which is mediated by a yet unidentified potassium channel. The BK channels appear to be involved in the repolarization of action potentials in GnRH neurons [57]. Inhibition of SK channels by apamin directly attenuates the mAHP as well as augments the afterdepolarization in GnRH neurons, and, thus, these channels exert a significant influence on the firing properties of these neurons $[58,59]$. Of the SK channel subtypes, only SK3 mRNA exhibits significant expression in GnRH neurons, and surge-inducing $\mathrm{E}_{2}$ treatments decrease the expression and function of this channel in ovariectomized females $[45,59]$. The channel responsible for the sAHP current has not been identified. However, this current slows or limits the firing frequency (called 'spike frequency adaptation') and is a major player controlling neuronal excitability [60]. A reduced AHP current allows a faster trajectory to burst firing of $\mathrm{GnRH}$ neurons $[25,56,59]$. Thus, the upregulation of low-voltage-activated $\left(\mathrm{Ca}_{V} 3.3\right)$ and HVA calcium $\left(\mathrm{Ca}_{V} 1.3,2.2\right.$, 2.3) and hyperpolarization-activated cation (HCN1) channels and the downregulation of SK3 channels by $\mathrm{E}_{2}$ play key roles in increasing GnRH neuronal excitability.

\section{Rapid $E_{2}$ Modulation of GnRH Neuronal Activity}

The relatively fast ( $\sim 15 \mathrm{~min}$ ) inhibition of GnRH and LH secretion by $E_{2}$ is congruent with its initiation of a membrane signaling cascade. In fact, years ago, it was found that guinea pig $\mathrm{GnRH}$ neurons are rapidly hyperpolarized by $\mathrm{E}_{2}$ via activation of an inwardly rectifying GIRK conductance in the presence of tetrodotoxin, which blocks fast $\mathrm{Na}^{+}$channel activity and isolates $\mathrm{GnRH}$ neurons from action potential-driven synaptic inputs $[47,61$, 62]. In mice, physiological concentrations (picomolar) of
$\mathrm{E}_{2}$ rapidly augment $\mathrm{K}_{\mathrm{ATP}}$ (also of the inwardly rectifying family) channel activity to hyperpolarize $\mathrm{GnRH}$ neurons [63]. $\mathrm{E}_{2}$ signals via a protein kinase C (PKC)-protein kinase A (PKA) pathway, and, hence, a selective Gaqmembrane-associated estrogen receptor (Gaq-mER) ligand called 'STX' are also able to mimic the effects of $\mathrm{E}_{2}$ in $\mathrm{GnRH}$ as in other hypothalamic neurons [63-66]. Both the effects of $E_{2}$ and STX are abrogated by the estrogen receptor antagonist ICI 182,780 with a $\mathrm{K}_{\mathrm{i}}$ of $0.5 \mathrm{nM}$ in GnRH neurons [63, 67], which is similar to the $K_{i}$ for the antagonism of ERa [68]. Interestingly, the membraneinitiated signaling by $\mathrm{E}_{2}$ in $\mathrm{GnRH}$ neurons appears to persist given that female mice treated with an $\mathrm{E}_{2}$ implant for 4-7 days similarly exhibit augmentation of the $\mathrm{K}_{\mathrm{ATP}}$ current, which attenuates GnRH neuronal firing [48]. This would imply that membrane-initiated signaling by $\mathrm{E}_{2}$ is involved in negative feedback regulation of $\mathrm{GnRH}$ neurons.

In addition, nanomolar concentrations of $E_{2}$ enhance action potential firing by modulating intrinsic afterhyperpolarizing and afterdepolarizing potentials via a PKAdependent mechanism involving ER $\beta$ [59]. Picomolar concentrations of $\mathrm{E}_{2}$ also inhibit action potential firing via presynaptic ER $\alpha$-dependent mechanisms [59]. $\mathrm{E}_{2}$ rapidly potentiates $\mathrm{HVA} \mathrm{Ca}^{2+}$ currents (L- and R-type $\mathrm{Ca}^{2+}$ channels) via ER $\beta$ and a G-protein-coupled receptor of $30-\mathrm{kDa}$ molecular weight (GPR30) suggesting that $\mathrm{Ca}^{2+}$ signaling is also a target for $\mathrm{E}_{2}$ membrane actions in GnRH neurons [41]. However, in slices prepared from GnRH-Pericam transgenic mice, $\mathrm{E}_{2}$ initiates calcium transients within $15 \mathrm{~min}$ in a subgroup of $\mathrm{GnRH}$ neurons [69]. In this transgenic mouse model, the $\mathrm{E}_{2}$ effects are mediated indirectly via input from GABA neurons that express ER $\alpha$. The role of ER $\beta$ to mediate rapid effects of $\mathrm{E}_{2}$ on $\mathrm{GnRH}$ neurons has also been shown following $\mathrm{E}_{2}$ treatment in vivo [70]. $\mathrm{E}_{2}$ rapidly (within $15 \mathrm{~min}$ ) phosphorylates cAMP response element-binding protein (pCREB) in GnRH neurons, an effect that is lost in ER $\beta$ deleted animals, supporting a direct role for ER $\beta$ in mediating rapid $\mathrm{E}_{2}$ signaling in $\mathrm{GnRH}$ neurons [70]. However, how pCREB affects gene expression and cell excitability is not known.

In primate and mouse embryonic nasal explants (the source of immature GnRH neurons), $\mathrm{E}_{2}$ modulates $\mathrm{Ca}^{2+}$ oscillations in GnRH neurons [71-74] which synchronize with a periodicity of approximately $60 \mathrm{~min}$ in primates, a rhythm that is similar to the pulsatile GnRH release [71, 73-75]. Furthermore, nanomolar concentrations of a membrane-impermeant $\mathrm{E}_{2}\left(\mathrm{E}_{2}\right.$ dendrimer $)$ and the Gq-mER ligand STX alter the patterns of $\mathrm{Ca}^{2+}$ oscil- 
lations in primate GnRH neurons $[75,76]$. As found previously with $\mathrm{E}_{2}$, STX also elicits an increase in the frequency and synchronization of $\mathrm{Ca}^{2+}$ oscillations in rhesus macaque GnRH neurons [75, 77]. The STX-induced modulation of $\mathrm{Ca}^{2+}$ oscillations (and $\mathrm{GnRH}$ release) from macaque nasal explants is not altered by GPR30 smallinterfering RNA transfection, suggesting that GPR30 is not involved. Importantly, the effects of STX are blocked by the ER antagonist ICI 182,780 and by the phospholipase C inhibitor U73122 [75]. This would suggest that STX $\left(\mathrm{E}_{2}\right)$ is activating Gq-mER (as defined above) in rhesus macaque GnRH neurons, which induces calcium oscillations via the IP3 receptor (fig. 1) and/or a PKC signaling pathway [78]. Therefore, although the specific role of membrane-initiated $\mathrm{E}_{2}$ signaling for $\mathrm{GnRH}$ physiology is uncertain, it could potentially play a critical role in sculpting GnRH burst firing activity.

\section{Kisspeptin-GnRH Neuronal Circuitry}

Kisspeptin 54 is the endogenous ligand of GPR54 (Kiss1R) [79]. GPR54 is highly expressed in GnRH neurons [45], and mutations in GPR54 cause autosomal recessive idiopathic hypogonadism in humans, and deletion of GPR54 or Kiss1 in mice results in defective sexual development and reproductive failure $[80,81]$. The Kiss 1 gene encodes a 145 -amino-acid protein, which is proteolytically processed to kisspeptin 54 and several other smaller peptide fragments, and centrally administered kisspeptins robustly stimulate $\mathrm{GnRH}$ and gonadotropin secretion in both prepubertal and adult animals $[82,83]$. Neurons in the AVPV/PeN areas express kisspeptin, GABA and opioid peptides, all of which are important for the regulation of GnRH neurosecretion [84-89]. The AVPV/PeN expresses high levels of ER $\alpha$ and also ER $\beta$, and the actions of the gonadal steroids on kisspeptin neurons are mediated, in part, via nuclear-initiated signaling (genomic) mechanisms [90-92]. Also, Kiss1 mRNA expression is greatly increased in the AVPV/PeN following $\mathrm{E}_{2}$ treatment [7]. These findings, combined with previous observations that lesions or antiestrogen implants of the AVPV/PeN in rodents abrogate the positive feedback effects of $\mathrm{E}_{2}$ [93-96], have led to the hypothesis that $\mathrm{E}_{2}$ acts on AVPV/PeN Kiss1 neurons to induce positive feedback on $\mathrm{GnRH}$ and LH secretion. Notably, an $\mathrm{E}_{2}$ treatment that induces an LH surge increases both the h-current and T-type calcium current in the AVPV/PeN Kiss1 neurons [14, 34].

Kisspeptin excites GnRH neurons primarily through activation of canonical transient receptor potential
(TRPC) channels and, to a lesser extent, through inhibition of inwardly rectifying $\mathrm{K}^{+}$channels (fig. 1 ) $[8-11,78$, 97]. In addition, kisspeptin induces a transient elevation of intracellular calcium in GnRH neurons, which is thought to be due to the release from intracellular calcium stores and has been hypothesized to play an important role in the kisspeptin-mediated depolarization [9]. However, the activation of TRPC channels in GnRH neurons by kisspeptin is not affected by buffering intracellular calcium levels by the calcium chelators EGTA or BAPTA or by depleting intracellular calcium stores [11, 78, 98]. Therefore, the release of calcium from intracellular stores does not appear to play a critical role in the kisspeptinmediated activation of TRPC channels but may be involved in the $\mathrm{Ca}^{2+} /$ calmodulin-dependent inhibition of HVA Ca ${ }^{2+}$ channels [99]. The kisspeptin-activated TRPC current is attenuated by the general calcium channel blocker $\mathrm{Cd}^{2+}$ and by the low-voltage-activated calcium channel blocker $\mathrm{Ni}^{2+}$ but not by the HVA calcium channel blocker amlodipine $[11,98]$. This would indicate that low-voltage-activated (T-type) calcium channels may be involved in facilitating TRPC channel opening. However, reducing extracellular calcium to nominally calcium free has no effect on the kisspeptin-activated TRPC current, an indication that very little calcium is needed to enable the opening of TRPC channels in GnRH neurons. This is consistent with the small, but persistent, T-type calcium channel activity (window current) around $-65 \mathrm{mV}$ in GnRH neurons [32]. Therefore, with a sustained depolarization that exceeds that of classical neurotransmitters (e.g., glutamate), kisspeptin excites GnRH neurons primarily through the opening of a TRPC channel that is independent of intracellular calcium store release but appears to be dependent on transient calcium influx through T-type calcium channels (fig. 1). This ensures a fast and yet sustained depolarization of GnRH neurons.

Although GnRH neurons express all of the TRPC channel subunits that are found in the brain (i.e., TRPC1, $3,4,5,6$, and 7), quanitative PCR analysis shows that TRPC4 is the main TRPC channel subtype in GnRH neurons and is expressed at levels 4-fold higher than TRPC1 and TRPC5 $[11,45]$. In fact, TRPC4 mRNA is increased in high $\mathrm{E}_{2}$-treated mice [45]. Phosphatidylinositol-4,5biphosphate $\left(\mathrm{PIP}_{2}\right)$ is an important regulator of TRPC channels, and depletion of $\mathrm{PIP}_{2}$ is required for kisspeptininduced TRPC channel activation in GnRH neurons [98]. In addition to $\mathrm{PIP}_{2}$ depletion, kisspeptin activation of TRPC channels is also dependent on the non-receptor tyrosine (cSrc) kinase activation (fig. 1), since both global tyrosine kinase inhibitors such as genistein and the spe- 
cific cSrc kinase inhibitor PP2 attenuate (inhibit) kisspeptin currents in GnRH neurons [98]. cSrc kinase directly regulates TPRC4 channel activity through tyrosine phosphorylation, which causes rapid insertion of TRPC4 channels into the plasma membrane [100]. Therefore, cSrc appears to be a key signaling molecule in the kisspeptin-mediated activation of TRPC channels in GnRH neurons.

PKC is an important second messenger stimulated by Gq-coupled receptors. However, PKC appears not to be involved in TRPC channel activation in cell lines expressing cloned TRPC channels [101]. Similarly, in GnRH neurons, $\mathrm{PKC}$ activation or inhibition has only a minor or no effect on the kisspeptin-induced inward TRPC current $[11,98]$.

Since the initial studies showing that kisspeptin has prolonged effects on GnRH neuronal activity [8-11], the question has been why is there very little spike frequency adaptation (slowing of action potential firing due to activation of $\mathrm{K}^{+}$channels) during kisspeptin-induced sustained firing? Recently, it has been shown that kisspeptin reduces spike frequency adaptation and prolongs firing via the inhibition of a calcium-activated slow AHP current $\left(\mathrm{I}_{\mathrm{SAHP}}\right)$ via PKC [56]. GnRH neurons express two distinct $I_{\text {SAHP }}$, an apamin-sensitive $[25,56]$ and a kisspeptinsensitive $I_{\mathrm{SAHP}}$ [56]. Essentially, kisspeptin inhibits $50 \%$ of the $\mathrm{I}_{\mathrm{SAHP}}$, and apamin inhibits the other $50 \%$ of the current [56]. Therefore, in addition to increasing the firing rate through an overt depolarization, kisspeptin facilitates sustained firing through inhibiting an apamin-insensitive $\mathrm{I}_{\mathrm{sAHP}}$ in $\mathrm{GnRH}$ neurons (via PKC). The physiological significance is that although single-action potential-generated calcium influx is sufficient to spark the release of classical neurotransmitters, burst firing or tetanic stimulation is required for the release of neuropeptides as first eloquently shown by Wakerly and Lincoln [102] in vivo and then in vitro by others [103-105].

\section{The Role of Pacemaker Currents in Kiss 1 Neurons}

Kiss1 neurons in the AVPV/PeN appear to be presynaptic pacemaker neurons that drive $\mathrm{GnRH}$ neurons. At least $50 \%$ of $\mathrm{GnRH}$ neurons receive monosynaptic input from the AVPV/PeN neurons, some of which have been identified as Kiss1 neurons [106]. Importantly, higherfrequency stimulation of AVPV/PeN neurons elicits a delayed excitatory response in $\mathrm{GnRH}$ neurons, which can be blocked by the kisspeptin inhibitory peptide 318 [106] . Recently, the development of Kiss1-CreGFP knock-in mice has allowed the targeting of GFP-expressing Kiss1 neurons for more detailed analysis [107] [for a review, see ref. 30]. Both $\mathrm{I}_{\mathrm{h}}$ and $\mathrm{I}_{\mathrm{T}}$ are prominently expressed in Kiss1 neurons [14, 34], and the Kiss1 neurons also express the corresponding critical transcripts $\mathrm{HCN} 1$ and $\mathrm{Ca}_{\mathrm{v}} 3.1$ [14]. In particular, $\mathrm{Ca}_{\mathrm{V}} 3.1$ calcium channels are highly expressed in AVPV/PeN Kiss1 neurons and are exceptionally sensitive to $\mathrm{E}_{2}$ [14; Zhang et al., in preparation]. The presence of a robust T-type calcium current is essential for the high-frequency rebound bursting that is manifested following a hyperpolarizing stimulus in these neurons [14].

In addition, Kiss1 neurons express a persistent $\mathrm{Na}^{+}$ current $\left(\mathrm{I}_{\mathrm{NaP}}\right)$ that is activated $\sim 10 \mathrm{mV}$ negative to the threshold for the transient sodium current in a membrane potential range in which few voltage-gated channels are activated and neuronal input resistance is high [14]. Thus, $\mathrm{I}_{\mathrm{NaP}}$ tends to amplify the depolarization induced by T-type calcium channels. Most importantly in terms of providing excitatory drive to $\mathrm{GnRH}$ neurons, an $\mathrm{E}_{2}$ treatment that produces an LH surge significantly increases both $\mathrm{I}_{\mathrm{h}}$ and $\mathrm{I}_{\mathrm{T}}$ in AVPV/PeN Kiss1 neurons by 3.4- and 6-fold, respectively [14, 34]. AVPV/PeN Kiss1 neurons rest at a relatively positive resting membrane potential of $-55 \mathrm{mV}$. Thus, some sort of robust inhibitory synaptic input is necessary for reaching hyperpolarized membrane potentials to recruit a critical mass of $\mathrm{Ca}_{\mathrm{V}} 3.1$ (by removing their inactivation) and $\mathrm{HCN} 1$ channels for initiating burst generation $[14,34]$.

Indeed, $\mathrm{GABA}$ via $\mathrm{GABA}_{\mathrm{B}}$ receptors (Gai/o coupled to GIRK channels) can provide the hyperpolarizing stimulus for generating burst firing [14]. GABA neurons are abundant in the hypothalamus, and the majority of Kiss1 neurons in the AVPV/PeN express GAD67 (glutamic acid decarboxylase, the GABA synthesizing enzyme) [108]. As such, Kiss1 neurons may themselves be an endogenous source of GABA, whose action could be autosynaptic and perhaps be responsible for hyperpolarizing Kiss1 neurons via $\mathrm{GABA}_{\mathrm{B}}$ receptors. Although further studies are needed to elucidate all of the physiological mechanisms underlying high-frequency burst firing of AVPV/PeN Kiss1 neurons, it is clear that these neurons express the critical channels and receptors that permit $\mathrm{E}_{2}$-dependent burst firing. Therefore, Kiss1 neurons, similar to thalamocortical neurons, express the critical pacemaker conductances, and, as such, Kiss 1 neurons have the capacity to generate bursting activity and excite GnRH neurons, which supports the idea that Kiss1 neurons provide the excitatory drive for $\mathrm{GnRH}$ surge secretion. 


\section{Conclusion}

What is critical for the control of GnRH neuronal excitability and ultimately the control of fertility is the hypothalamic circuitry. This 'circuitry' not only includes the synaptic input to kisspeptin and GnRH neurons but also the effects of circulating $E_{2}$, which conveys vital feedback information about reproductive states, on the excitability of these neurons. All AVPV/PeN kisspeptin neurons express the endogenous burst-generating conductances $\left(\mathrm{I}_{\mathrm{h}}\right.$, $\mathrm{I}_{\mathrm{T}}$ and $\mathrm{I}_{\mathrm{NaP}}$ ) that allow these vital neurons to generate burst firing and release kisspeptin, which in turn excites GnRH neurons that also express $\mathrm{I}_{\mathrm{h}}, \mathrm{I}_{\mathrm{T}}$ and $\mathrm{I}_{\mathrm{NaP}}[22,32,48$, 106]. A future challenge is not only to identify all of the key channels and signaling molecules and how they are regulated by $\mathrm{E}_{2}$ but also how these channels fit into the kisspeptin-GnRH neuronal circuitry for the generation of burst firing and peptide release.

\section{Acknowledgments}

The authors thank current and previous members of their laboratories who contributed to the work described in the present review. We also thank Dr. Casey C. Nestor for the helpful comments on the earlier version of the manuscript, and Ms. Marina V. Rulevskaya and Ms. Uyen-Vy Navarro for their excellent technical support. The work from the authors' laboratories was supported by PHS grants NS 43330, NS 38809 and DK 68098.

\section{References}

1 Terasawa E, Rodriguez JS, Bridson WE, Wiegand SJ: Factors influencing the positive feedback action of estrogen upon luteinizing hormone surge in the ovariectomized guinea pig. Endocrinology 1979;104:680-686.

-2 Caraty A, Locatelli A, Martin GB: Biphasic response in the secretion of gonadotrophin-releasing hormone in ovariectomized ewes injected with oestradiol. J Endocrinol 1989;123: 375-382.

$\checkmark 3$ Chappell PE, Levine JE: Stimulation of gonadotropin-releasing hormone surges by estrogen. 1. Role of hypothalamic progesterone receptors. Endocrinology 2000;141:1477-1485.

$\checkmark 4$ Spergel DJ, Kruth U, Hanley DF, Sprengel R, Seeburg PH: GABA- and glutamate-activated channels in green fluorescent protein-tagged gonadotropin-releasing hormone neurons in transgenic mice. J Neurosci 1999;19:20372050.

5 Suter KJ, Song WJ, Sampson TL, Wuarin J-P, Saunders JT, Dudek FE, Moenter SM: Genetic targeting of green fluorescent protein to gonadotropin-releasing hormone neurons: characterization of whole-cell electrophysiological properties and morphology. Endocrinology 2000;141:412-419.

-6 Fujioka H, Suzuki M, Yamanouchi K, Ohta A, Nagashima H, Kato M, Nishihara M: Generation of transgenic rats expressing enhanced green fluorescent protein in gonadotropinreleasing hormone neurons. J Reprod Dev 2003;49:523-529.

7 Smith JT, Cunningham MJ, Rissman EF, Clifton DK, Steiner RA: Regulation of Kiss1 gene expression in the brain of the female mouse. Endocrinology 2005;146:3686-3692.
8 Han S-K, Gottsch ML, Lee KJ, Popa SM, Smith JT, Jakawich SK, Clifton DK, Steiner RA, Herbison AE: Activation of gonadotropin-releasing hormone neurons by kisspeptin as a neuroendocrine switch for the onset of puberty. J Neurosci 2005;25:11349-11356.

$\checkmark 9$ Liu X, Lee K, Herbison AE: Kisspeptin excites gonadotropin-releasing hormone $(\mathrm{GnRH})$ neurons through a phospholipase $\mathrm{C} /$ calciumdependent pathway regulating multiple ion channels. Endocrinology 2008;149:4605-4614.

$>10$ Pielecka-Fortuna J, Chu Z, Moenter SM: Kisspeptin acts directly and indirectly to increase gonadotropin-releasing hormone neuron activity and its effects are modulated by estradiol. Endocrinology 2008;149:1979-1986.

$\checkmark 11$ Zhang C, Roepke TA, Kelly MJ, Rønnekleiv $\mathrm{OK}$ : Kisspeptin depolarizes gonadotropin-releasing hormone neurons through activation of TRPC-like cationic channels. J Neurosci 2008;28:4423-4434.

12 Kelly MJ, Rønnekleiv OK: Electrophysiological analysis of neuroendocrine neuronal activity in hypothalamic slices; in Levine JE (ed): Methods in Neurosciences: Pulsatility in Neuroendocrine Systems. San Diego, Academic Press, 1994, pp 47-67.

13 Bosch MA, Zhang C, Rønnekleiv OK: Regulation of endogenous conductances in $\mathrm{GnRH}$ neurons by estrogens. Brain Res 2010;1364. 25-34.

14 Zhang C, Tonsfeldt KJ, Qiu J, Bosch MA, Kobayashi K, Steiner RA, Kelly MJ, Rønnekleiv OK: Molecular mechanisms that drive estradiol-dependent burst firing of Kiss1 neurons in the rostral periventricular preoptic area. Am J Physiol Endocrinol Metab 2013; 305:E1384-E1397.

15 McCormick DA, Huguenard JR: A model of the electrophysiological properties of thalamocortical relay neurons. J Neurophysiol 1992;68:1384-1400.
16 Lüthi A, McCormick DA: H-current: properties of a neuronal and network pacemaker. Neuron 1998;21:9-12.

17 Kim D, Song I, Keum S, Lee T, Jeong MJ, Kim SS, McEnery MW, Shin HS: Lack of the burst firing of thalamocortical relay neurons and resistance to absence seizures in mice lacking alpha (1G) T-type $\mathrm{Ca}(2+)$ channels. Neuron 2001;31:35-45.

18 Kelly MJ, Wagner EJ: GnRH neurons and episodic bursting activity. Trends Endocrinol Metab 2002;13:409-410.

19 Lyons DJ, Horjales-Araujo E, Broberger C: Synchronized network oscillations in rat tuberoinfundibular dopamine neurons: switch to tonic discharge by thyrotropin-releasing hormone. Neuron 2010;65:217-229.

20 Chen X, Iremonger K, Herbison A, Kirk V, Sneyd J: Regulation of electrical bursting in a spatiotemporal model of a GnRH neuron. Bull Math Biol 2013;75:1941-1960.

21 Moenter SM, Anthony DR, Pitts GR, Nunemaker CS: Mechanisms underlying episodic gonadotropin-releasing hormone secretion. Front Neuroendocrinol 2003;24:79-93.

22 Chu Z, Moenter SM: Physiologic regulation of a tetrodotoxin-sensitive sodium influx that mediates a slow afterdepolarization potential in gonadotropin-releasing hormone neurons: possible implications for the central regulation of fertility. J Neurosci 2006;26:1196111973.

23 Popa SM, Clifton DK, Steiner RA: The role of kisspeptins and GPR54 in the neuroendocrine regulation of reproduction. Annu Rev Physiol 2008;70:14.1-14.26.

24 Colledge WH: Kisspeptins and GnRH neuronal signalling. Trends Endocrinol Metab 2009;3:115-121. 
25 Lee K, Duan W, Sneyd J, Herbison AE: Two slow calcium-activated afterhyperpolarization currents control burst firing dynamics in gonadotropin-releasing hormone neurons. J Neurosci 2010;30:6214-6224.

26 Herbison AE, Moenter SM: Depolarising and hyperpolarising actions of GABA(A) receptor activation on gonadotrophin-releasing hormone neurons: towards an emerging consensus. J Neuroendocrinol 2011;23:557-569.

-27 Pielecka-Fortuna J, DeFazio RA, Moenter SM: Voltage-gated potassium currents are targets of diurnal changes in estradiol feedback reglation and kisspeptin action on gonadotropin-releasing hormone neurons in mice. Biol Reprod 2011;85:987-995.

-28 Chu Z, Tomaiuolo M, Bertram R, Moenter SM: Two types of burst firing in gonadotropin-releasing hormone neurones. J Neuroendocrinol 2012;24:1065-1077.

-29 Frazão R, Cravo RM, Donato J Jr, Ratra DV, Clegg DJ, Elmquist JK, Zigman JM, Williams KW, Elias CF: Shift in Kiss1 cell activity requires estrogen receptor $\alpha$. J Neurosci 2013; 33:2807-2820.

-30 Piet R, de Croft S, Liu X, Herbison AE: Electrical properties of kisspeptin neurons and their regulation of GnRH neurons. Front Neuroendocrinol 2014, DOI: 10.1016/j.yfrne.2014. 05.006 .

-31 Huguenard JR, Prince DA: A novel T-type current underlies prolonged $\mathrm{Ca}^{2+}$-dependent burst firing in GABAergic neurons of rat thalamic reticular nucleus. J Neurosci 1992;12: 3804-3817.

- 32 Zhang C, Bosch MA, Rick EA, Kelly MJ, Rønnekleiv OK: $17 \beta$-Estradiol regulation of Ttype calcium channels in gonadotropin-releasing hormone neurons. J Neurosci 2009; 29:10552-10562.

33 Chu Z, Takagi H, Moenter SM: Hyperpolarization-activated currents in gonadotropinreleasing hormones $(\mathrm{GnRH})$ neurons contribute to intrinsic excitability and are regulated by gonadal steroid feedback. J Neurosci 2010;30:13373-13383.

-34 Piet R, Boehm U, Herbison AE: Estrous cycle plasticity in the hyperpolarization-activated current $I_{h}$ is mediated by circulating $17 \beta$ estradiol in preoptic area kisspeptin neurons. J Neurosci 2013;33:10828-10839.

- 35 Perez-Reyes E, Cribbs LL, Daud A, Lacerda AE, Barclay J, Williamson MP, Margaret F, Rees M, Lee J-H: Molecular characterization of a neuronal low-voltage-activated T-type calcium channel. Nature 1998;391:896-900.

36 Lee J-H, Daud AN, Cribbs LL, Lacerda AE, Pereverzev A, Klockner U, Schneider T, Perez-Reyes E: Cloning and expression of a novel member of the low voltage-activated T-type calcium channel family. J Neurosci 1999;19: 1912-1921.
Chemin J, Monteil A, Perez-Reyes E, Bourinet E, Nargeot J, Lory P: Specific contribution of human T-type calcium channel isotypes (alpha(1G), alpha(1H) and alpha(1I)) to neuronal excitability. J Physiol 2002;540:3-14.

38 Kato M, Ui-Tei K, Watanabe M, Sakuma Y: Characterization of voltage-gated calcium currents in gonadotropin-releasing hormone neurons tagged with green fluorescent protein in rats. Endocrinology 2003;144:51185125.

39 Cueni L, Canepari M, Lujan R, Emmenegger Y, Watanabe M, Bond CT, Franken P, Adelman JP, Luthi A: T-type $\mathrm{Ca}^{2+}$ channels, SK2 channels and SERCAs gate sleep-related oscillations in thalamic dendrites. Nat Neurosci 2008;11:683-692.

40 Liu S, Shipley MT: Multiple conductances cooperatively regulate spontaneous bursting in mouse olfactory bulb external tufted cells. J Neurosci 2008;28:1625-1639.

41 Sun J, Chu Z, Moenter SM: Diurnal in vivo and rapid in vitro effects of estadiol on voltage-gated calcium channels in gonadotropinreleasing hormone neurons. J Neurosci 2010; 30:3912-3923.

42 Nunemaker CS, DeFazio RA, Moenter SM: Calcium current subtypes in GnRH neurons. Biol Reprod 2003;69:1914-1922.

43 Spergel DJ: Calcium and small-conductance calcium-activated potassium channels in gonadotropin-releasing hormone neurons before, during, and after puberty. Endocrinology 2007;148:2383-2390.

44 Tanaka N, Ishii H, Yin C, Koyama M, Sakuma Y, Kato M: Voltage-gated $\mathrm{Ca}^{2+}$ channel mRNAs and T-type $\mathrm{Ca}^{2+}$ currents in rat gonadotropin-releasing hormone neurons. J Physiol Sci 2010;60:195-204.

45 Bosch MA, Tonsfeldt KJ, Rønnekleiv OK: mRNA expression of ion channels in GnRH neurons: subtype-specific regulation by $17 \beta$ estradiol. Mol Cell Endocrinol 2013;367:8597.

46 Christian CA, Mobley JL, Moenter SM: Diurnal and estradiol-dependent changes in gonadotropin-releasing hormone neuron firing activity. Proc Natl Acad Sci USA 2005;102: 15682-15687.

47 Lagrange $\mathrm{AH}$, Rønnekleiv OK, Kelly MJ: Estradiol- $17 \beta$ and $\mu$-opioid peptides rapidly hyperpolarize GnRH neurons: a cellular mechanism of negative feedback? Endocrinology 1995;136:2341-2344.

48 Zhang C, Bosch MA, Levine JE, Rønnekleiv OK, Kelly MJ: Gonadotropin-releasing hormone neurons express K(ATP) channels that are regulated by estrogen and responsive to glucose and metabolic inhibition. J Neurosci 2007;27:10153-10164

49 Hille B: Potassium channels and chloride channels; in Hille B (ed): Ion Channels of Excitable Membranes. Sunderland, Sinauer, 2001, pp 131-165.
$50 \mathrm{Wu}$ M, Dumalska I, Morozova E, Van den Pol AN, Alreja M: Melanin-concentrating hormone directly inhibits GnRH neurons and blocks kisspeptin activation, linking energy balance to reproduction. Proc Natl Acad Sci USA 2009;106:17217-17222.

51 Zhang C, Bosch MA, Rønnekleiv OK, Kelly $\mathrm{MJ}: \mathrm{GABA}_{\mathrm{B}}$ receptor mediated inhibition of $\mathrm{GnRH}$ neurons is suppressed by kisspeptinGPR54 signaling. Endocrinology 2009;150: 2388-2394.

$52 \mathrm{Xu}$ J, Kirigiti MA, Cowley MA, Grove KL, Smith MS: Suppression of basal spontaneous gonadotropin-releasing hormone neuronal activity during lactation: role of inhibitory effects of neuropeptide Y. Endocrinology 2009; 150:333-340.

53 Bosch MA, Kelly MJ, Rønnekleiv OK: Distribution, neuronal co-localization and $17 \beta-\mathrm{E}_{2}$ modulation of small conductance calciumactivated $\mathrm{K}^{+}$channel (SK3) mRNA in the guinea pig brain. Endocrinology 2002;143: 1097-1107.

54 Kato M, Tanaka N, Usui S, Sakuma Y: SK channel blocker apamin inhibits slow afterhyperpolarization currents in rat gonadotropinreleasing hormone neurons. J Physiol 2006; 574:431-442.

55 Wang Y, Kuehl-Kovarik MC: Flufenamic acid modulates multiple currents in gonadotropin-releasing hormone neurons. Brain Res 2010;1353:94-105.

56 Zhang C, Rønnekleiv OK, Kelly MJ: Kisspeptin inhibits a slow afterhyperpolarization current via protein kinase $\mathrm{C}$ and reduces spike-frequency adaptation in GnRH neurons. Am J Physiol Endocrinol Metab 2013; 304:E1237-E1244.

57 Hiraizumi Y, Nishimura I, Ishii H, Tanaka N, Takeshita T, Sakuma Y, Kato M: Rat GnRH neurons exhibit large conductance voltageand $\mathrm{Ca}^{2+}$-activated $\mathrm{K}^{+}(\mathrm{BK})$ currents and express BK channel mRNAs. J Physiol Sci 2008; 58:21-29.

58 Liu X, Herbison AE: Small-conductance calcium-activated potassium channels control excitability and firing dynamics in gonadotropin-releasing hormone ( $\mathrm{GnRH})$ neurons. Endocrinology 2008;149:3598-3604.

59 Chu Z, Andrade J, Shupnik MA, Moenter SM: Differential regulation of gonadotropin-releasing hormone neuron activity and membrane properties by acutely applied estradiol: dependence on dose and estrogen receptor subtype. J Neurosci 2009;29:5616-5627.

60 Sah P, Faber ESL: Channels underlying neuronal calcium-activated potassium currents. Prog Neurobiol 2002;66:345-353.

61 Kelly MJ, Rønnekleiv OK, Eskay RL: Identification of estrogen-responsive LHRH neurons in the guinea pig hypothalamus. Brain Res Bull 1984;12:399-407.
Kisspeptin and GnRH Neuronal Excitability
Neuroendocrinology 2015;102:184-193 DOI: $10.1159 / 000370311$ 
62 Condon TP, Rønnekleiv OK, Kelly MJ: Estrogen modulation of the $\alpha_{1}$-adrenergic response of hypothalamic neurons. Neuroendocrinology 1989;50:51-58.

-63 Zhang C, Kelly MJ, Rønnekleiv OK: $17 \beta$-Estradiol rapidly increases ATP-sensitive potassium channel activity in gonadotropinreleasing hormone neurons via a protein kinase signaling pathway. Endocrinology 2010; 151:4477-4484

64 Lagrange AH, Rønnekleiv OK, Kelly MJ: Modulation of G-protein-coupled receptors by an estrogen receptor that activates protein kinase A. Mol Pharmacol 1997;51:605-612.

-65 Qiu J, Bosch MA, Tobias SC, Grandy DK, Scanlan TS, Rønnekleiv OK, Kelly MJ: Rapid signaling of estrogen in hypothalamic neurons involves a novel G-protein-coupled estrogen receptor that activates protein kinase C. J Neurosci 2003;23:9529-9540.

66 Qiu J, Bosch MA, Tobias SC, Krust A, Graham S, Murphy S, Korach KS, Chambon P, Scanlan TS, Rønnekleiv OK, Kelly MJ: A Gprotein-coupled estrogen receptor is involved in hypothalamic control of energy homeostasis. J Neurosci 2006;26:5649-5655.

67 Rønnekleiv OK, Zhang C, Kelly MJ: Estradiol and kisspeptin modulation of gonadotropinreleasing hormone $(\mathrm{GnRH})$ neuronal excitability; in Armstong WE, Tasker JG (eds): Neurophysiology of Neuroendocrine Neurons. Hoboken, John Wiley and Sons, 2014, pp 301-321.

68 Weatherill PJ, Wilson APM, Nicholson RI, Davies P, Wakeling AE: Interaction of the antioestrogen ICI 164,384 with the oestrogen receptor. J Steroid Biochem 1988;30:263-266.

69 Romanò N, Lee K, Ábrahám IM, Jasoni CL, Herbison AE: Non-classical estrogen modulation of presynaptic GABA terminals modulates calcium dynamics in gonadotropin-releasing hormone $(\mathrm{GnRH})$ neurons. Endocrinology 2008;149:5335-5344.

-70 Abraham IM, Han SK, Todman MG, Korach KS, Herbison AE: Estrogen receptor beta mediates rapid estrogen actions on gonadotropin-releasing hormone neurons in vivo. J Neurosci 2003;23:5771-5777.

71 Terasawa E, Schanhofer WK, Keen KL, Luchansky LL: Intracellular $\mathrm{Ca}^{2+}$ oscillations in luteinizing hormone-releasing hormone neurons derived from the embryonic olfactory placode of the rhesus monkey. J Neurosci 1999;19:5898-5909.

-72 Richter TA, Keen KL, Terasawa E: Synchronization of $\mathrm{Ca}^{2+}$ oscillations among primate LHRH neurons and nonneuronal cells in vitro. J Neurophysiol 2002;88:1559-1567.

73 Temple JL, Laing E, Sunder A, Wray S: Direct action of estradiol on gonadotropin-releasing hormone-1 neuronal activity via a transcription-dependent mechanism. J Neurosci 2004; 24:6326-6333.
74 Temple JL, Wray S: BSA-estrogen compounds differentially alter gonadotropin-releasing hormone-1 neuronal activity. Endocrinology 2005; 146:558-563.

75 Kenealy BP, Keen KL, Rønnekleiv OK, Terasawa E: STX, a novel nonsteroidal estrogenic compound, induces rapid action in primate GnRH neuronal calcium dynamics and peptide release. Endocrinology 2011;152:182191.

76 Abe H, Keen KL, Terasawa E: Rapid action of estrogens on intracellular calcium oscillations in primate LHRH-1 neurons. Endocrinology 2008;149:1155-1162.

77 Kenealy BP, Keen KL, Terasawa E: Rapid action of estradiol in primate $\mathrm{GnRH}$ neurons: the role of estrogen receptor alpha and estrogen receptor beta. Steroids 2011;76:861-866.

78 Constantin S, Caligioni CS, Stojilkovic S, Wray S: Kisspeptin-10 facilitates a plasma membrane-driven calcium oscillator in gonadotropin-releasing hormone-1 neurons. Endocrinology 2009;150:1400-1412.

79 Kotani M, Detheux M, Vandenbogaerde A, Communi D, Vanderwinden J-M, Le Poul E, Brezillon S, Tyldesley R, Suarez-Huerta N, Vandeput F, Blanpain C, Schiffmann SN, Vassart G, Parmentier M: The metastasis suppressor gene KiSS-1 encodes kisspeptins, the natural ligands of the orphan $\mathrm{G}$ protein-coupled receptor GPR54. J Biol Chem 2001;276: 34631-34636.

-80 Seminara SB, Messager S, Chatzidaki EE, Thresher RR, Acierno JS, Shagoury JK, BoAbbas Y, Kuohung W, Schwinof KM, Hendrick AG, Zahn D, Dixon J, Kaiser UB, Slaugenhaupt SA, Gusella JF, O'Rahilly S, Carlton MBL, Crowley WF, Aparicio SA Jr, Colledge WH: The GPR54 gene as a regulator of puberty. N Engl J Med 2003;349:1614-1627.

81 d'Anglemont de Tassigny X, Fagg LA, Dixon JPC, Day K, Leitch HG, Hendrick AG, Zahn D, Franceschini I, Caraty A, Carlton MBL, Aparicio SA Jr, Colledge WH: Hypogonadotropic hypogonadism in mice lacking a functional KiSS 1 gene. Proc Natl Acad Sci USA 2007;104:10714-10719.

82 Gottsch ML, Cunningham MJ, Smith JT, Popa SM, Acohido BV, Crowley WF, Seminara S, Clifton DK, Steiner RA: A role for kisspeptins in the regulation of gonadotropin secretion in the mouse. Endocrinology 2004; 145:4073-4077.

83 Kinoshita M, Tsukamura H, Adachi S, Matsui $\mathrm{H}$, Uenoyama $\mathrm{Y}$, Iwata K, Yamada S, Inoue K, Ohtaki T, Matsumoto H, Maeda K-I: Involvement of central metastin in the regulation of preovulatory luteinizing hormone surge and estrous cyclicity in female rats. Endocrinology 2005; 146:4431-4436

84 Simerly RB, McCall LD, Watson SJ: Distribution of opioid peptides in the preoptic region: immunohistochemical evidence for a steroidsensitive enkephalin sexual dimorphism. J Comp Neurol 1988;276:442-459.
85 Wagner EJ, Rønnekleiv OK, Bosch MA, Kelly MJ: Estrogen biphasically modifies hypothalamic GABAergic function concomitantly with negative and positive control of luteinizing hormone release. J Neurosci 2001;21: 2085-2093.

86 Jackson GL, Kuehl D: Gamma-aminobutyric acid (GABA) regulation of $\mathrm{GnRH}$ secretion in sheep. Reproduction 2002;59:15-24.

87 DeFazio RA, Heger S, Ojeda SR, Moenter SM: Activation of A-type gamma-aminobutyric receptors excites gonadotropin-releasing hormone neurons. Mol Endocrinol 2002;16: 2872-2891.

- 88 Smith JT, Popa SM, Clifton DK, Hoffman GE, Steiner RA: Kiss1 neurons in the forebrain as central processors for generating the preovulatory luteinizing hormone surge. J Neurosci 2006;26:6687-6694.

89 Christian CA, Moenter SM: Estradiol induces diurnal shifts in GABA transmission to gonadotropin-releasing hormone neurons to provide a neural signal for ovulation. J Neurosci 2007;27:1913-1921.

90 Shughrue PJ, Lane MV, Merchenthaler I: Comparative distribution of estrogen receptor- $\alpha$ and $-\beta$ mRNA in the rat central nervous system. J Comp Neurol 1997;388:507525

91 Wintermantel TM, Campbell RE, Porteous R, Bock D, Gröne H-J, Todman MG, Korach KS, Greiner E, Perez CA, Schultz G, Herbison AE: Definition of estrogen receptor pathway critical for estrogen positive feedback to gonadotropin-releasing hormone neurons and fertility. Neuron 2006;52:271-280.

92 Clarkson J, d'Anglemont de Tassigny X, Moreno AS, Colledge WH, Herbison AE: Kisspeptin-GPR54 signaling is essential for preovulatory gonadotropin-releasing hormone neuron activation and the luteinizing hormone surge. J Neurosci 2008;28:8691-8697.

93 Wiegand SJ, Terasawa E, Bridson WE: Persistent estrus and blockade of progesterone-induced LH release follows lesions which do not damage the suprachiasmatic nucleus. Endocrinology 1978;102:1645-1648.

94 Rønnekleiv OK, Kelly MJ: Plasma prolactin and luteinizing hormone profiles during the estrous cycle of the female rat: effects of surgically induced persistent estrus. Neuroendocrinology 1988;47:133-141.

-95 Petersen SL, Barraclough CA: Suppression of spontaneous LH surges in estrogen-treated ovariectomized rats by microimplants of antiestrogens into the preoptic brain. Brain Res 1989;484:279-289.

96 Ma YJ, Kelly MJ, Rønnekleiv OK: Pro-gonadotropin-releasing hormone (ProGnRH) and GnRH content in the preoptic area and the basal hypothalamus of anterior medial preoptic nucleus/suprachiasmatic nucleus-lesioned persistent estrous rats. Endocrinology 1990; 127:2654-2664. 
97 Kroll H, Bolsover S, Hsu J, Kim S-H, Bouloux P-M: Kisspeptin-evoked calcium signals in isolated primary rat gonadotropinreleasing hormone neurones. Neuroendocrinology 2011;93:114-120.

98 Zhang C, Bosch MA, Rønnekleiv OK, Kelly MJ: Kisspeptin activation of TRPC4 channels in female $\mathrm{GnRH}$ neurons requires $\mathrm{PIP}_{2}$ depletion and cSrc kinase activation. Endocrinology 2013;154:2772-2783.

$\checkmark 99$ Zhang X-B, Spergel DJ: Kisspeptin inhibits high-voltage activated $\mathrm{Ca}^{2+}$ channels in $\mathrm{GnRH}$ neurons via multiple $\mathrm{Ca}^{2+}$ influx and release pathways. Neuroendocrinology 2012;96:68-80.

100 Odell AF, Scott JL, Van Helden DF: Epidermal growth factor induces tyrosine phosphorylation, membrane insertion, and activation of transient receptor potential channel 4. J Biol Chem 2012;280:37974-37987.
101 Birnbaumer L: The TRPC class of ion channels: a critical review of their roles in slow, sustained increases in intracellular $\mathrm{Ca}^{2+}$ concentrations. Annu Rev Pharmacol Toxicol 2009;49:395-426.

102 Wakerley JB, Lincoln DW: The milk-ejection reflex of the rat: a 20 - to 40 - fold acceleration in the firing of paraventricular neurones during oxytocin release. J Endocrinol 1973;57:477-493.

103 Bicknell RJ: Optimizing release from peptide hormone secretory nerve terminals. J Exp Biol 1988;139:51-65.

104 Shakiryanova D, Tully A, Hewes RS, Deitcher DL, Levitan ES: Activity-dependent liberation of synaptic neuropeptide vesicles. Nat Neurosci 2005;8:173-178.

105 Masterson SP, Li J, Bickford ME: Frequencydependent release of substance $\mathrm{P}$ mediates heterosynaptic potentiation of glutamatergic synaptic responses in the rat visual thalamus. J Neurophysiol 2010;104:1758-1767.
06 Liu X, Porteous R, d'Anglemont de Tassigny X, Colledge WH, Millar R, Petersen SL, Herbison AE: Frequency-dependent recruitment of fast amino acid and slow neuropeptide neurotransmitter release controls gonadotropin-releasing hormone neuron excitability. J Neurosci 2011;31:2421-2430.

107 Gottsch ML, Popa SM, Lawhorn JK, Qiu J, Tonsfeldt KJ, Bosch MA, Kelly MJ, Rønnekleiv OK, Sanz E, McKnight GS, Clifton DK, Palmiter RD, Steiner RA: Molecular properties of Kiss1 neurons in the arcuate nucleus of the mouse. Endocrinology 2011; 152:4298-4309.

108 Cravo RM, Margatho LO, Osborne-Lawrence S, Donato J Jr, Atkin S, Bookout AL, Rovinsky S, Frazão R, Lee CE, Gautron L, Zigman JM, Elias CF: Characterization of Kiss1 neurons using transgenic mouse models. Neuroscience 2011;173:37-56. 